\title{
Effect of Easiness, Service Quality, Price, Trust of Quality of Information, and Brand Image of Consumer Purchase Decision on Shopee Online Purchase
}

\author{
Goldianus Solangius Mbete ${ }^{1}$, Rinabi Tanamal ${ }^{2}$ \\ ${ }^{1,2}$ The Department of Information Systems, Faculty of Information Technology, Ciputra University, \\ Citraland CBD Boulevard, Made, Kec. Sambikerep, Surabaya, Jawa Timur, Indonesia, 60219 \\ e-mail: ${ }^{1}$ goldianussm@gmail.com, ${ }^{2}$ r.tanamal@ ciputra.ac.id
}

Submitted Date: April $27^{\text {th }}, 2020$

Revised Date: May $28^{\text {th }}, 2020$
Reviewed Date: May $11^{\text {th }}, 2020$

Accepted Date: June 29 ${ }^{\text {th }}, 2020$

\begin{abstract}
Technological developments are so rapid to bring impact and influence to all areas of life without exception e-commerce. Recent advances in web-based technologies and applications lead to the emergence of new developments that affect electronic trading. Trade of e-commerce encourages consumers to actively participate in the purchase and sale of products and services in the market and online community. However, the effect on the factors that influence and make the consumer are interested of trading the e-commerce marketplace/ platform has not yet achieved the right formula and is not well understood, causing policymaking are less effective in increasing consumer purchase decisions can thus have a negative impact on online purchase behavior of consumers. In this study proposed several variables that are considered influential in the purchase decision of the consumer (such as convenience, quality of service, price, trust, information quality and brand image) that will be modeled in the form of a hypothesis and the next will be in to do testing to prove the hypothesis on the independent variables proposed. The results of the study shows that the ease and brand image have a positive significant impact on purchase decisions online in the marketplace Shopee. While the quality of service, price, trust and information quality has no significant effect on purchasing decisions online in the marketplace Shopee. Shopee can maintain and evaluate the level of convenience and a brand image that is already good and improve the quality of service, price, trust and information quality as an effort to improve the purchase decision of the consumers.
\end{abstract}

Keywords: Brand Image; Customer Trust; Easiness; E-commerce; Information Quality; Price; Purchase Decision; Quality of Service; Shopee; TAM

\section{Introduction}

Technological developments are so rapid to bring impact and influence to all areas of life without exception e-commerce. Recent advances in web-based technologies and application as well as its emergence the concept of social media has led to the emergence of new developments that affect electronic trading. From some e-commerce are the focus on the smartphone, current Shopee is a most in download. As for the fact, that increasing the e-commerce industry in Indonesia is influenced by the style of shopping online, especially by the millennial generation. According to Indonesia's Millennial Report 2019, millennial is very like looking for a price comparison, features, program, schedule and quality of products in some e-commerce before deciding to buy an item (idEA, 2019). A millennial will also give advice to friends of his who want to shop on e-commerce or store the favorite based on the experience that has been passed. The trade of ecommerce encourages consumers to actively participate in the purchase and sale of products and services in the market and online community. However, the effect on the factors that influence and make the consumer are interested of trading the e-commerce marketplace/ platform has not yet achieved the right formula and is not well understood, causing policy-making less effective thus can have a negative impact on online purchase behavior of consumers. In this study proposed several variables that are considered influential in the purchase decision of the consumer (such as convenience, quality of service, price, trust, information quality, and brand image). One of the factors that attract the buying interest of consumers, namely the ease. Each marketplace or anyone selling online should consider the ease in 
accessing and obtaining the goods needed by the consumer. Because by increasing the ease of it will make consumer feel comfortable and feel easy in obtaining the good that, the goods or services needed or wanted. This will give benefit from the consumer in giving the decision to make a purchase or otherwise do not want to make a purchase. Based on the description above, the researcher decided to use the variable ease as one of the independent variables to determine the purchase decision. Researchers choose variables ease of on the marketplace Shopee because based on the results of pre survey conducted by the researchers of the twenty-respondents there were six respondents who provide answers do not agree if the application Shopee easy to use and easy to learn. Therefore, the researchers were interested to enter the variable ease in research to determine the effect of the variable ease of the purchase decision with larger samples.

On the discussion above has been explained about the ease factor, then on the next point to be discussed regarding the quality of the service. Service quality is the assessment of long-term provided by the consumer on the service provided based on the evaluation of cognitive. Companies that consistently provide the best service then it will get an edge over the competition, more freely and easily in fostering the loyalty of the consumer. In this case, the success of a company or business is based also from the factors of service quality (service quality). Researchers are interested to take the variable quality of service because based on the results of the pre survey a lot of respondents who give a negative answer to the application service Shopee which includes a page on the app Shopee often error, personal data and finances are not secure. Good service can certainly consider consumers to make a purchase. Therefore, the researchers wanted to prove whether the quality of the service is already provided or not in accordance with the expectations and needs of consumers.

After the ease and quality of information, then the researchers chose price as a third variable. Price is the amount of money as a medium of exchange to acquire products or services Kotler and Armstrong (2006). Researchers are interested to take up variable rates because of the goods that are in sell on the marketplace Shopee able to compete with the marketplace a kind of where the offer is very varied and there are even cheaper because the goods imported directly from abroad and thus formed a much cheaper price than the market price. Price is one factor that can affect a person for the purchase decision states that the price significantly influence the purchase decision (Rizki, Hidayat, \& Devita, 2019).

The next variable used in this study is trust. Beliefs and attitudes there as a result of the action and the learning process done so that consumers affect buying behavior. Trust is the result of the translation of thoughts descriptive of something, while attitude is a pattern of structured of motivation, perception, emotional feelings and cognitive processes on an aspect. One of the fundamental things into consideration a person in the conduct of shopping online is whether they believe in the marketplace/website which provides service of the online shop and believe by the seller that exist on online websites that. In addition, this study was conducted because of the differences in the results between research conducted by Rozieqy and Arifin (Rozieqy \& Arifin, 2018) stated that trust significantly influence the purchase decision. However inversely proportional to the research done by Ayuningtiyas and Gunawan (Ayuningtiyas \& Gunawan, 2018) in the journal of the research, which stated that, the trust did not significantly influence the purchase decision. This shows that the trust become important factors that need to be improved and cared for by all the businesses online in an effort to create a good relationship with the consumer.

After the four variables above the next researchers to choose the variable quality of information as a fifth variable. The researchers chose the variable quality of information on the marketplace Shopee due to the presence of symptoms there is a discrepancy between the quality of the products and the information in the description about the product description of some of the stores that sell their products in the marketplace Shopee. It can be seen from the ratings given to consumers after making a purchase so as to make the prospective consumer Shopee must see and pay attention to the rating of each product along with reviews of the product before making a purchase. The information displayed on the online sites should encompass quality information and in accordance with the product displayed. The information needs of consumers can be met by providing product information that must be ter up to date so that able to give consideration to consumers in making decisions and easy to understand. If the information presented and provided to the consumer quality then the higher interest of 
consumers to make purchase decision of a product is needed. This is supported by research conducted by Ayuningtiyas and Gunawan (Ayuningtiyas \& Gunawan, 2018), which stated that information quality significantly influence the purchase decision.

The variables selected by the researcher is the brand image. Brand image (Brand Image) is an exposure of the overall perception that is formed through the information and past experiences of a brand (Sanjiwani \& Suasana, 2019). Brand image is very important for a company to be able to increase the confidence of consumers when using their products. Brand image great influence on the development of the company. The formation of the image on the company can be positive or negative depending on the perception of consumers who have used the product. It also affects the high and low levels of product sales at the company. The presence of a positive image which is implanted to a brand from the consumers make a lot of companies developing and delivering improvements to the power consumers will buy the product. This is supported by research conducted by Rizki, Hidayat, and Devita (Rizki, Hidayat, \& Devita, 2019) who stated that brand image significantly influence the purchase decision.

Based on the analysis and description that has been described above, it can be concluded that the researcher will conduct the research with the proposed variable ease, quality of service, price, trust, quality information and brand image on purchase decisions on the purchase of online shopee.

\section{The Foundation of The Theory}

\subsection{Technology Acceptance Model (TAM)}

The Technology Acceptance Model (TAM) is a method first introduced by Fred Davis (Davis, 1989), TAM is a useful method to find out what factors make people accept or reject and want to use information technology (in Tanamal, 2019). Figure 1 is a picture of the initial construction of the TAM introduced by David.

\subsection{Shopee}

Shopee is one of the applications that can be used on android and the OS and can make it easy for consumers to search and obtain the desired product with an affordable price without being limited by distance and time (Wijaya \& Warnadi, 2019).

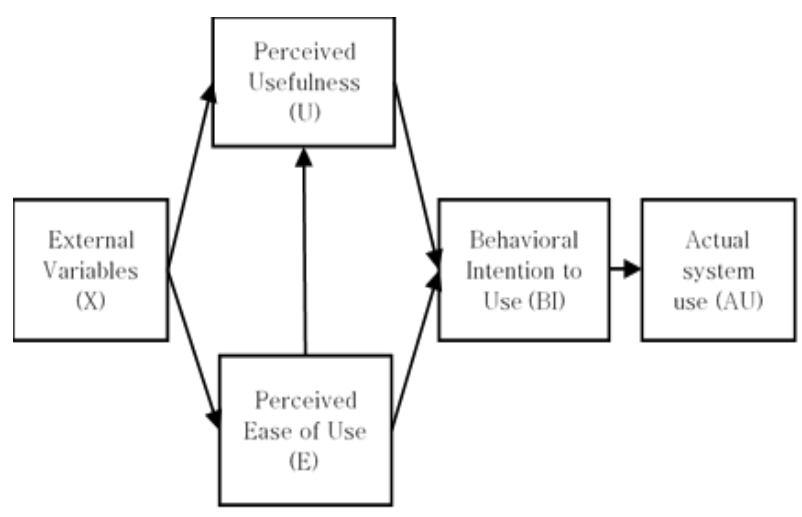

Figure 1. Technology Acceptance Model

\subsection{Easiness}

According to Chin and Todd (Chin \& Todd, 1995) they explain the ease of as an influence that is felt is relatively easy to use and understand related to technology and process the transaction online. Suhir, Suyadi, and Riyadi (Suhir, Suyadi, \& Riyadi, 2014) (2014) divide the variables of ease in some of the indicators that consist of:

1. Easy to interact,

2. Easy to do transactions,

3. Easy to get the product,

4. Easy to learn, and

5. Easy to use.

Ease can also be defined the extent to which consumers can feel free of effort to do or get something (Wijaya \& Warnadi, 2019).

\subsection{Service Quality}

The concept of service is the result of translation and a form of fusion between the detection of needs by and with the customer, itself creates a planning. Service changes include the implementation of a service with the set operation capability (ability and resources) in the distribution of services in the provider side and also the customer. The distribution service also covers all the activities of the provider for consumption of services, including support services, and recovery services (Winkler \& Wulf, 2019).

\subsection{Price}

According to Kotler and Armstrong (2006) price is the amount of money as a medium of exchange to acquire products or services or it can also be said of the determination of the value of a product in the minds of consumers (in Abshor, Hasiolan, \& Malik, 2018). Price is relative because of its dependence on the reference concerns the 
utility derived from the product of a non-reference, one could argue that the product reference may be a higher price than the product of the nonreference (Amaldoss \& He, 2017).

\subsection{Trust}

Trust comes from the expectations of consumers towards a product where when these expectations are not met then consumer confidence will be reduced even disappear (Wijaya \& Warnadi, 2019). Trust and attitude in consumer emerge because of the action and the learning process that does the consumer affect the buying behavior. The trust itself is an idea that belongs to someone against something, while attitude is a unity of motivation, perception, emotional feelings and psychological processes to something. Confidence is knowledge, opinion or just believe in something. The trust will give a good impression to the image and brand of a product, while the attitude is more towards how the consistency should be shown by the consumer in the behave toward the same object.

\subsection{Quality of Information}

According to Mowen and Minor (in Rozieqy \& Arifin, 2018) information can be defined as messages exchanged from it all. According to Sutabri (2012), three things determine the quality of information as follows:

1. Accuracy is the information required to be able to describe a situation that is definite and error free.

2. Timeliness that is never too late in presenting information.

3. Relevance means that information can be matched with the desires and useful for the wearer.

\subsection{Brand Image}

Brand image is defined as the set of the view either that are positive or otherwise negative towards a brand that is owned by the consumer. The view of the opposition of the brand meaning for consumers as the information that will be stored in the memory that of course they will be used as a guide in determining something (Lowry, Vance, Moody, Beckman, \& Read, 2014). Kotler (2002) defines brand image is a unity between the idea, the belief, and the impression of a brand that is inherent in a person. Therefore, brand image is a representation of the general perception that is fashioned through the statistics and previous trip of a company such (Sanjiwani \& Suasana, 2019).

\subsection{Purchase Decision}

Kotler and Armstrong (2012) explain that the purchase decision illustrates a stage where consumers have no choice on a product and ready to do the purchase or exchange and promise to pay with the right of possession or use of a product (in Wijaya \& Warnadi, 2019:155).

According to Afroz (2013) a purchasing decision is an attitude of using and willing to buy a product whether in the form of goods or services that are felt to be able to satisfy their wants or needs and are willing to take risks against the decisions that have been taken. Interpretation of cognitive factors and consumer persona is very useful and has a strong influence on the attitude of purchasing a product or service from its products and companies. (In Sanjiwani \& Suasana, 2019).

Suryani (in Rozieqy \& Arifin, 2018) explained that there were five roles in purchasing decisions, namely:

1. The initiator (initiator), namely the giver of ideas whose task is to initiate the process of purchasing goods or services.

2. Carrier influence (influencer) is an idea attached to an individual who is then transmitted to be an influence on purchasing decisions in others.

3. Decider (decider), namely people who have the right to determine purchasing decisions based on considerations.

4. The buyer (buyer), namely people who spend money to get goods or services.

2. User (user), that is, people use goods or services

\section{Methodology}

This research uses quantitative research with inferential statistics (inductive / probability), parametric statistics and univariate statistics. The quantitative a research method used to behavior lookup on particular populations or samples, using research instruments in data collection, using statistical data analysis, and the aim is to test hypotheses that have been formed.

"Inferential statistics are part of statistics that discuss how to do data analysis, predict and draw conclusions on data, phenomena, broader problems (population) based on part of the data taken randomly from the population. Parametric statistics are statistical techniques used to test population parameters through statistics or to test population sizes through sample data. The use of parametric statistics in testing hypotheses often 
requires assumptions about the distribution or distribution of data such as assumptions of normality, homogeneity, and linearity of data Univariate statistics are statistical techniques that only involving one dependent variable in their analysis regardless of how many independent variables" (Machali, 2018).

\subsection{Analysis Model}

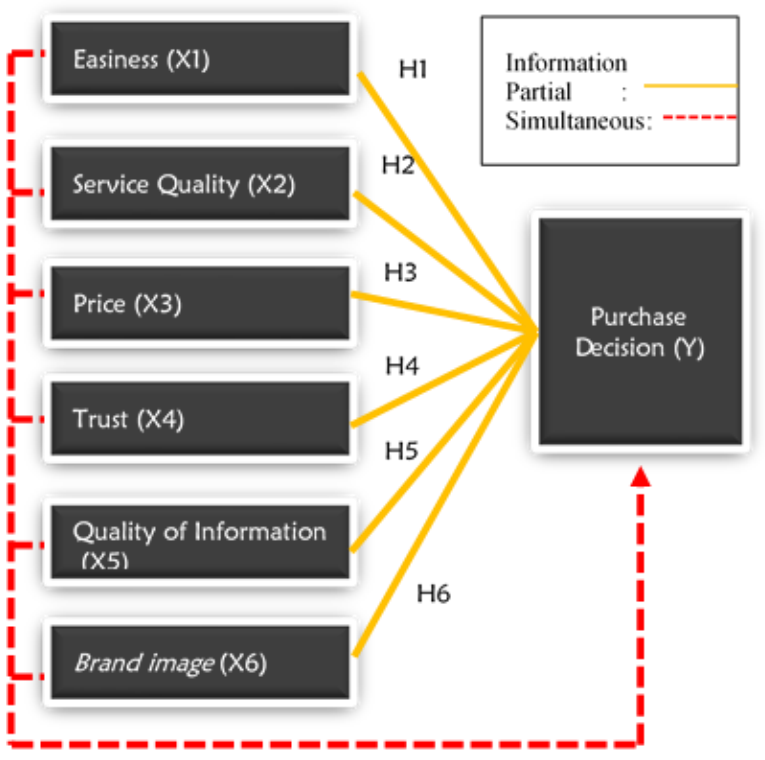

Figure 2. Analysis Model

\subsection{Hypothesis Table}

Table 1 - Hypothesis Table

\begin{tabular}{|c|l|l|}
\hline Hypothesis & \multicolumn{1}{|c|}{ Information } & Reference \\
\hline $\mathrm{H}_{1}$ & $\begin{array}{l}\text { Ease of positive and } \\
\text { significant influence } \\
\text { on consumer } \\
\text { purchasing } \\
\text { decisions on online } \\
\text { Shopee purchases }\end{array}$ & $\begin{array}{l}\text { Rozieqy \& } \\
\text { Arifin (2018) }\end{array}$ \\
\hline \multirow{3}{*}{$\mathrm{H}_{2}$} & $\begin{array}{l}\text { Quality of service } \\
\text { has a positive and } \\
\text { significant effect on } \\
\text { consumer } \\
\text { purchasing } \\
\text { decisions on online } \\
\text { Shopee purchases }\end{array}$ & $\begin{array}{l}\text { Andrew } \\
\text { (2019) }\end{array}$ \\
\hline $\mathrm{H}_{3}$ & $\begin{array}{l}\text { Price and a } \\
\text { significant positive } \\
\text { effect on consumer } \\
\text { purchasing } \\
\text { decisions on online } \\
\text { Shopee purchases }\end{array}$ & $\begin{array}{l}\text { Rizki, } \\
\text { Hidayat, \& } \\
\text { Devita } \\
\text { (2019) }\end{array}$ \\
\hline
\end{tabular}

\begin{tabular}{|c|l|l|}
\hline Hypothesis & \multicolumn{1}{|c|}{ Information } & \multicolumn{1}{|c|}{ Reference } \\
\hline \multirow{3}{*}{$\mathrm{H}_{4}$} & $\begin{array}{l}\text { Trust has a positive } \\
\text { and significant } \\
\text { effect on consumer } \\
\text { purchasing } \\
\text { decisions on online } \\
\text { Shopee purchases }\end{array}$ & $\begin{array}{l}\text { Rozieqy \& } \\
\text { Arifin (2018) }\end{array}$ \\
\hline \multirow{3}{*}{$\mathrm{H}_{5}$} & $\begin{array}{l}\text { Information quality } \\
\text { has a positive and } \\
\text { significant effect on } \\
\text { consumer } \\
\text { purchasing } \\
\text { decisions on online } \\
\text { Shopee purchases }\end{array}$ & $\begin{array}{l}\text { Ayuningtiyas } \\
\text { \& Gunawan } \\
\text { (2018) }\end{array}$ \\
\hline $\mathrm{H}_{6}$ & $\begin{array}{l}\text { Brand image has a } \\
\text { positive and } \\
\text { significant influence } \\
\text { on consumer } \\
\text { purchasing } \\
\text { decisions on online } \\
\text { Shopee purchases }\end{array}$ & $\begin{array}{l}\text { Rizki, } \\
\text { Hidayat, \& } \\
\text { Devita } \\
\text { (2019) }\end{array}$ \\
\hline
\end{tabular}

\subsection{Data Collection}

In collecting data in this study, steps were taken by determining the variables and measurement scale of the data set to be used in the research instrument. "Likert scale is used to measure people's attitudes, opinions, and perceptions about phenomena and social problems that arise in the midst of society. In researching these social phenomena and problems, it has already been determined by the researcher, hereinafter referred to as a variable (Machali, 2018). By using a Likert scale respondents can provide their answers based on the results of their experience who have used and transacted in the Shopee application by selecting one of the 4 answers as follows:

Table 2 - Instrument Scale

\begin{tabular}{|c|c|}
\hline Answer & Value \\
\hline Very Agree & Score 4 \\
\hline Agree & Score 3 \\
\hline Disagree & Score 2 \\
\hline Very Disagree & Score 1 \\
\hline
\end{tabular}

Likert scale in this study does not use the answer "doubtful", with the aim to eliminate the tendency of answers that are at a safe point. So later respondents who are afraid to give answers will tend to choose the "hesitant" answer to remain in a safe position. So, the researcher decides to choose the 4 categories of answers above to see the certainty of the respondents' opinions in the 
direction of agreeing or vice versa in the direction of disagreeing.

\subsection{Population}

According to Machali (2018) population is the completeness of objects / subjects that have been determined by researchers based on a number or certain characteristics. Morgan (2004) defines "population as the whole object of research consisting of humans, objects, animals, plants, symptoms, test scores, or events as sources of data that have certain characteristics in a study" (in Machali, 2018: p. 218). Based on the definition above, the population in this study are consumers who have bought and used Shopee in Surabaya. While the number of consumers who use the Shopee marketplace is unknown and falls into the population category with an infinite number.

\subsection{Sample}

The sample is a small part of the completeness of objects that are considered to represent the entirety of the population under study (Machali, 2018:217). In general, the sampling method can be categorized into two methods, the Probability Sampling Method and the NonProbability Sampling Method.

In this study, the sample was determined using the Non-Probability Sampling method and the technique used was purposive sampling. In the Non-Probability Sampling method, the sample is not given equal opportunity or opportunity for each element or member of the population to be chosen as a sample. "Purposive sampling is a sampling technique with certain considerations carried out by the researchers themselves based on the characteristics or characteristics of the population that have been previously known" (Machali, 2018:227). Considerations taken by researchers in this study are people who have used and transacted at least twice on the Shopee application and also who are domiciled in Surabaya.

In this study, the sampling approach used to be taken the usage of a nonprobability sampling method. According to Rao Purba (1996), if the total population is unknown, the formula for finding a minimum sample is done by the formula

$$
\mathrm{n}=\frac{Z^{2}}{4(M o e)^{2}}
$$

Where:

$\mathrm{n}=$ Number of samples
$\mathrm{Z}=$ normal level of distribution at a significant level of $5 \%=1,96$

Moe $=$ Margin of Error Max, which is the maximum error rate of sampling that can still be tolerated or desired

Using a maximum error margin of $10 \%$, the minimum number of samples that can be taken are:

$$
\begin{aligned}
& \mathrm{n}=\frac{(1,96)^{2}}{4(0,10)^{2}} \\
& \mathrm{n}=96,04 \text { or } 96 \text { respondents }
\end{aligned}
$$

Based on a theoretical study and calculation of the minimum number of samples to be used above, the researchers narrowed the population of online Shopee shopping agents in Surabaya to a sample of 155 respondents.

\subsection{Measurement Indicator}

The following question indicators for:

1. Easiness

a. Shopee application is easy in ordering products

b. Shopee application is easy in product payments

c. Shopee application is easy in product delivery

d. The Shopee application is easy to use by anyone

e. The Shopee application is easy for anyone to learn

2. Quality of service

a. The system in the Shopee application can always be accessed for buying and selling activities

b. The page in the Shopee application does not experience an error

c. My personal data is protected on the Shopee application

d. My financial data and transaction data are protected on the Shopee application

3. Price

a. Some products sold in the Shopee application have lower prices than other e-commerce sites

b. The Shopee application provides a price match to the quality of the product

c. Shopee application provides attractive prices with vouchers / free postage promos

4. Trust

a. I am sure that Shopee owners / sellers can be held responsible 
b. I am sure that shopping at Shopee will fulfill its desires.

c. I am confident in the performance of Shopee sellers

d. I am sure that Shopee products can meet the needs

e. I am sure that Shopee vendors / sellers can serve consumers well

5. Quality Information

a. Information about the products offered is always up to date on the Shopee application

b. Information about products is always relevant to the Shopee application

c. Information about products is easily understood in the Shopee application

6. Brand Image
a. I can easily remember the Shopee brand
b. I shop at Shopee because of the free shipping facilities
c. Shopee is a top priority site or application when I want to shop online
d. Shopee is a brand that others recommend when I want to shop online

7. Buying decision
a. I often use Shopee to shop
b. I am looking for information about the categories of items to be purchased on the Shopee application
c. I will always shop at Shopee
d. I like shopping at Shopee
e. I am looking for information about shopping experiences at Shopee through friends and relatives who have shopped at Shopee
f. Shopee offers several payment variations

\subsection{Test Validity and Reliability Test 3.8.1 Validity Test}

A measuring instrument is said to be valid or has a high validity value if the measuring instrument can indeed measure what we want to measure (Machali, 2018:183):

a. if the value of $r$ count $>r$ table then the measurement tool used can be said to be valid

b. if the value of $r$ count $<r$ table then the measuring instrument used is not valid.

\subsubsection{Reliability Test}

A research measuring instrument can be said to have a reliability value if the results of the test instrument have a constant result of something that is about to be measured (Machali, 2018:p196). According to Mudrajad Kuncoro (in Tanamal,
2019) reliability indicates the stability or consistency of the score (measurement scale). Validity Test is done using Cronbach's Alpha, where if the Cronbach's Alpha value $>0,7$, then it can be declared reliable.

\section{$4 \quad$ Result and Discussion}

Table 3 - Characteristics of Respondents

\begin{tabular}{|c|c|c|}
\hline Gender & Frequency & Percentage \\
\hline Male & 54 & $34,8 \%$ \\
\hline Female & 101 & $65,2 \%$ \\
\hline \multicolumn{3}{|l|}{ Age } \\
\hline 17 years or less & 1 & $0.6 \%$ \\
\hline $18-25$ years old & 147 & $94.9 \%$ \\
\hline $26-35$ years old & 7 & $4.5 \%$ \\
\hline 36 years or more & - & - \\
\hline \multicolumn{3}{|l|}{ Profession } \\
\hline Student & 121 & $78,1 \%$ \\
\hline Employee & 23 & $14,8 \%$ \\
\hline Housewife & - & - \\
\hline Etc & 11 & $7,1 \%$ \\
\hline \multicolumn{3}{|l|}{ Types of products } \\
\hline Menswear & 28 & $18, \%$ \\
\hline Women's clothing & 62 & $40 \%$ \\
\hline Beauty tools & 67 & $43,2 \%$ \\
\hline Home Appliance & 22 & $14,2 \%$ \\
\hline Mother \& Baby & 4 & $2,6 \%$ \\
\hline Medical devices & 7 & $4,5 \%$ \\
\hline Men's bag & 7 & $4,5 \%$ \\
\hline Women's bag & 23 & $14,8 \%$ \\
\hline Muslim fashion & 3 & $1,9 \%$ \\
\hline Fashion Accessories & 39 & $25,2 \%$ \\
\hline Hobbies \& Collections & 39 & $25,2 \%$ \\
\hline Food \& Beverage & 25 & $16,1 \%$ \\
\hline Automotive & 6 & $3,9 \%$ \\
\hline Voucher & 10 & $6,5 \%$ \\
\hline Souvenirs \& Parties & 7 & $4,5 \%$ \\
\hline $\begin{array}{l}\text { Hand phones \& } \\
\text { Accessories }\end{array}$ & 47 & $30,3 \%$ \\
\hline $\begin{array}{ll}\text { Computers } & \& \\
\text { Accessories } & \\
\end{array}$ & 26 & $16,8 \%$ \\
\hline $\begin{array}{l}\text { Baby \& Children's } \\
\text { Fashion }\end{array}$ & 1 & $0,6 \%$ \\
\hline Men \& Women's Shoes & 23 & $14,8 \%$ \\
\hline Personal Care Products & 23 & $14,8 \%$ \\
\hline Wristwatch & 8 & $5,2 \%$ \\
\hline Electronic & 30 & $19,4 \%$ \\
\hline Health & 7 & $4,5 \%$ \\
\hline Photography & 7 & $4,5 \%$ \\
\hline Sports \& Outdoors & 18 & $11,6 \%$ \\
\hline Books \& Stationery & 18 & $11,6 \%$ \\
\hline Various & 24 & 15,5 \\
\hline
\end{tabular}




\subsection{Measurement of Validity Test and Reliability Test}

Validity test is done to assess valid or not a measuring instrument. In order to test the validity should meet the criteria namely if the value of $r$ count $>r$ table using a significance value of $5 \%$ or $\alpha=0.05$ and degrees of freedom $(\mathrm{df}=\mathrm{n}-2)$ then the measuring instrument used can be said to be valid and vice versa if the value of $r$ count $<r$ table using $\alpha=0.05$, then the measuring instrument used is not valid.

Table 4 - Validity Test Results

\begin{tabular}{|c|c|c|c|}
\hline Variable & & $R$ table & Note \\
\hline Eeasiness & K count & K tadie & Note \\
\hline $\mathrm{A} 1$ & 0,674 & 0,157 & Valid \\
\hline A2 & 0,653 & 0,157 & Valid \\
\hline A3 & 0,668 & 0,157 & Valid \\
\hline A4 & 0,735 & 0,157 & Valid \\
\hline A5 & 0,769 & 0,157 & Valid \\
\hline Variable & \multirow{2}{*}{$\mathrm{R}$ count } & \multirow{2}{*}{$\mathrm{R}$ table } & \multirow{2}{*}{ Note } \\
\hline Service Quality & & & \\
\hline B1 & 0,693 & 0,157 & Valid \\
\hline B2 & 0,755 & 0,157 & Valid \\
\hline B3 & 0,815 & 0,157 & Valid \\
\hline B4 & 0,755 & 0,157 & Valid \\
\hline Variable & \multirow{2}{*}{$\mathrm{R}$ count } & \multirow{2}{*}{$\mathrm{R}$ table } & \multirow{2}{*}{ Note } \\
\hline Price & & & \\
\hline $\mathrm{C} 1$ & 0,791 & 0,157 & Valid \\
\hline $\mathrm{C} 2$ & 0,793 & 0,157 & Valid \\
\hline $\mathrm{C} 3$ & 0,754 & 0,157 & Valid \\
\hline Variable & \multirow{2}{*}{$\mathrm{R}$ count } & \multirow{2}{*}{$\mathrm{R}$ table } & \multirow{2}{*}{ Note } \\
\hline Trust & & & \\
\hline $\mathrm{D} 1$ & 0,781 & 0,157 & Valid \\
\hline $\mathrm{D} 2$ & 0,729 & 0,157 & Valid \\
\hline D3 & 0,817 & 0,157 & Valid \\
\hline D4 & 0,767 & 0,157 & Valid \\
\hline D5 & 0,797 & 0,157 & Valid \\
\hline Variable & \multirow[b]{2}{*}{$\mathrm{R}$ count } & \multirow[b]{2}{*}{$\mathrm{R}$ table } & \multirow[b]{2}{*}{ Note } \\
\hline $\begin{array}{l}\text { Quality of } \\
\text { information }\end{array}$ & & & \\
\hline E1 & 0,791 & 0,157 & Valid \\
\hline E2 & 0,840 & 0,157 & Valid \\
\hline E3 & 0,797 & 0,157 & Valid \\
\hline Variable & \multirow{2}{*}{$\mathrm{R}$ count } & \multirow{2}{*}{$\mathrm{R}$ table } & \multirow{2}{*}{ Note } \\
\hline Brand Image & & & \\
\hline $\mathrm{F} 1$ & 0,627 & 0,157 & Valid \\
\hline $\mathrm{F} 2$ & 0,704 & 0,157 & Valid \\
\hline F3 & 0,759 & 0,157 & Valid \\
\hline F4 & 0,624 & 0,157 & Valid \\
\hline Variable & \multirow[b]{2}{*}{$\mathrm{R}$ count } & \multirow[b]{2}{*}{$\mathrm{R}$ table } & \multirow[b]{2}{*}{ Note } \\
\hline $\begin{array}{l}\text { Purchase } \\
\text { Decision }\end{array}$ & & & \\
\hline G1 & 0,782 & 0,157 & Valid \\
\hline $\mathrm{G} 2$ & 0,631 & 0,157 & Valid \\
\hline
\end{tabular}

\begin{tabular}{|c|c|c|c|}
\hline G3 & 0,777 & 0,157 & Valid \\
\hline G4 & 0,814 & 0,157 & Valid \\
\hline G5 & 0,652 & 0,157 & Valid \\
\hline G6 & 0,513 & 0,157 & Valid \\
\hline
\end{tabular}

The reliability test is performed to measure and determine the level of reliability of the instruments used. The value of Cronbach's Alpha is used as a reliability analysis of the instrument. This test was conducted on 155 respondents. Decisionmaking is based on the table 5 about the interpretation of the value of the Cronbach's Alpha:

Table 5 - Interpretation of Cronbach's Alpha Numbers

\begin{tabular}{|c|c|}
\hline Cronbach's Alpha & Interpretasi \\
\hline$\alpha>0,9$ & Perfect \\
\hline$\alpha>0,7$ & High \\
\hline $0,5 \leq \alpha<0,7$ & Moderate \\
\hline$\alpha<0,5$ & Low \\
\hline
\end{tabular}

The instrument can be relied upon if the answer is consistent from time to time.

Table 6 - Reliability Test Results

\begin{tabular}{|l|c|c|}
\hline \multicolumn{1}{|c|}{ Variable } & $\begin{array}{c}\text { Number of } \\
\text { Indicators }\end{array}$ & $\begin{array}{c}\text { Cronbach's } \\
\text { Alpha Score }\end{array}$ \\
\hline Easiness & 5 & 0,839 \\
\hline Quality of Service & 4 & 0,837 \\
\hline Price & 3 & 0,845 \\
\hline Trust & 5 & 0,831 \\
\hline $\begin{array}{l}\text { Information } \\
\text { Quality }\end{array}$ & 3 & 0,832 \\
\hline Brand image & 4 & 0,822 \\
\hline Purchase Decision & 6 & 0,823 \\
\hline
\end{tabular}

\subsection{Multiple Linear Regression Test}

Multiple regression is an analysis tool used to see whether there is a functional or causal relationship between independent variables namely Ease, Quality Of Service, Price, Trust, Quality Of Information, And Brand Image to a dependent variable Purchase Decision with the following equation

$$
\begin{aligned}
\mathrm{Y}= & 0.004+0.162 \mathrm{X}_{1}+0.103 \mathrm{X}_{2}+0.061 \mathrm{X}_{3}+ \\
& 0.125 \mathrm{X}_{4}-0.040 \mathrm{X}_{5}+0.549 \mathrm{X}_{6}
\end{aligned}
$$


Table 7 - Results of Multiple Linear Regression

\begin{tabular}{|l|c|c|}
\hline \multirow{2}{*}{ Model } & $\begin{array}{c}\text { Unstandardized } \\
\text { Coefficients }\end{array}$ & t \\
\cline { 2 - 3 } & B & 0,014 \\
\hline (Constant) & 0,004 & 2,080 \\
\hline Easiness & 0,162 & 1,530 \\
\hline $\begin{array}{l}\text { Quality of } \\
\text { Service }\end{array}$ & 0,103 & 0,902 \\
\hline Price & 0,061 & $-0,560$ \\
\hline Trust & 0,125 & 7,760 \\
\hline $\begin{array}{l}\text { Information } \\
\text { Quality }\end{array}$ & $-0,040$ & \multicolumn{2}{|c|}{$0,752,121$} \\
\hline Brand image & 0,549 \\
\hline F & \multicolumn{2}{|c|}{0,566} \\
\hline R & \multicolumn{2}{|c|}{0,548} \\
\hline$R^{2}$ & $\begin{array}{l}\text { Adjusted R } \\
\text { Square }\end{array}$ & \multicolumn{2}{|c|}{0} \\
\hline
\end{tabular}

\subsection{Partial Significance Test (t-Test)}

A T-test is a test used to determine the effect of each independent variable on the dependent variable. A T-test is a test to determine the significance of the independent variable whether it has a partial effect on the dependent variable. In the t-test you can do a comparison between arithmetic and t tables.

While the testing criteria are as follows, the significant level $(\alpha=0.05)$ where if the significance value $<0.05$, it can be concluded that the independent variable partially has a significant effect on the dependent variable. Basic criteria for decision making if $\mathrm{t}$ arithmetic $>\mathrm{t}$ table, then $\mathrm{H} 0$ is rejected and $\mathrm{H} 1$ is accepted and if $\mathrm{t}$ arithmetic $<\mathrm{t}$ table, then $\mathrm{HO}$ is accepted and $\mathrm{H} 1$ is rejected.

Table 8 - T-Test Results

\begin{tabular}{|l|c|c|c|}
\hline \multirow{2}{*}{ Model } & $\begin{array}{c}\text { Unstandardize } \\
\mathrm{d} \text { Coefficients }\end{array}$ & \multirow{2}{*}{$\mathrm{t}$} & \multirow{2}{*}{ Sig. } \\
\cline { 2 - 3 } (Constant) & 0,004 & 0,014 & 0,989 \\
\hline Easiness & 0,162 & 2,080 & 0,039 \\
\hline $\begin{array}{l}\text { Quality of } \\
\text { Service }\end{array}$ & 0,103 & 1,530 & 0,128 \\
\hline Price & 0,061 & 0,902 & 0,369 \\
\hline Trust & 0,125 & 1,726 & 0,086 \\
\hline $\begin{array}{l}\text { Information } \\
\text { Quality }\end{array}$ & $-0,040$ & $-0,560$ & 0,576 \\
\hline Brand image & 0,549 & 7,760 & 0,000 \\
\hline
\end{tabular}

Based on the results of the t-test analysis on the ease variable $\left(\mathrm{X}_{1}\right)$ the significance value was $0.039<0.05$. The $t$ value is $2,080>1,976 \mathrm{t}$ table. It can be concluded that the comfort variable has a significant influence on customer satisfaction. Then hypothesis 1 is accepted.

Based on the results of the t-test analysis on the service quality variable $\left(\mathrm{X}_{2}\right)$, the significance value is $0.128>0.05$. For the value of arithmetic which is $1.530<1,976 \mathrm{t}$ table. It can be concluded that the service quality variable does not have a significant influence on purchasing decisions. Then hypothesis 2 is rejected.

Based on the results of the t-test analysis on the price variable $\left(\mathrm{X}_{3}\right)$ that is equal to $0.369>0.05$. The value of arithmetic is $0.902<1,976 \mathrm{t}$ table. It can be concluded that the price variable does not have a significant influence on purchasing decisions. Then hypothesis 3 is rejected.

Based on the results of the analysis of t-test on the variable of trust $\left(\mathrm{X}_{4}\right)$ that is equal to $0,086>$ 0,05 . For the value of the count is $1,726<1,976 t$ table. It can be concluded that the variables trust does not have a significant influence on the purchase decision. Then hypothesis 4 is rejected.

Based on the results of the t-test analysis on the information quality variable $\left(\mathrm{X}_{5}\right)$ that is equal to $0.576>0.05$. For the value of arithmetic -0.560 $<1,976 \mathrm{t}$ table. It can be concluded that the information quality variable has no significant influence on purchasing decisions. Then hypothesis 5 is rejected.

Based on the results of the $t$ test analysis on the Brand Image variable $\left(\mathrm{X}_{6}\right)$ that is equal to $0,000<0.05$. For the value of arithmetic is 7,760> $1,976 \mathrm{t}$ tables. It can be concluded that brand image variables have a significant influence on customer satisfaction. Then hypothesis 6 is accepted.

\subsection{Simultaneous Significance Test (F Test)}

The $F$ test is used to test the effect of the overall independent variable namely ease, service quality, price, trustworthiness, information quality and brand image on the dependent variable, namely online purchasing decisions:

1. If Physics> F table then $\mathrm{H} 0$ is rejected $\mathrm{H} 1$ is accepted, it means that there is an effect of easiness, service quality, price, trustworthiness, information quality and brand image on online purchasing decisions in Shopee.

2. If Fithmetic $<\mathrm{F}$ table then $\mathrm{H} 0$ is accepted H1 is rejected, meaning there is no effect of easiness, service quality, price, trustworthiness, quality of information and brand image on online purchasing decisions in Shopee: 
Table 9 - F-Test Results

\begin{tabular}{|c|c|c|c|}
\hline Model & df & F & Sig \\
\hline Regression & 6 & 32,123 & 0,000 \\
\hline
\end{tabular}

Based on the formula $(\mathrm{k} ; \mathrm{n}-\mathrm{k})$, the value obtained to find $f$ table $(6 ; 155-6)=(6 ; 149)$, then the distribution of $f$ table obtained a value of 2,16 .

In Table 9, the calculated f value of 32.121 is greater than the $\mathrm{f}$ table value of 2.16. Significance value is 0.00 less than 0.05 according to the basis of decision making, it can be concluded that the variables of easiness, service quality, price, trustworthiness, information quality and brand image simultaneously and have a positive direction in influencing purchase decisions on the Shopee marketplace.

\subsection{Test of Determination Coefficient}

The coefficient of determination $\left(\mathrm{R}^{2}\right)$ is an analytical tool contained in multiple linear regression tests, which is used to measure how much the ability of independent variables in explaining the dependent variable.

Table 10 - Determination Coefficient Test Results

\begin{tabular}{|l|l|l|}
\hline Model & R Square & Adjusted R Square \\
\hline 1 & 0,566 & 0,548 \\
\hline
\end{tabular}

Based on table 10, $\mathrm{R}$ square value of 0.566 shows that the independent variables, namely easiness, service quality, price, trustworthiness, information quality, and brand image can explain the dependent variable, namely the buying decision of $56.6 \%$. While the rest is explained by other independent variables not included in this study.

\section{Conclusions}

Based on the results of the evaluation conducted, it can be concluded that partly (t-test) the ease and brand image variables have a massive superb impact on purchasing decisions in the Shopee utility in Surabaya, variable service quality, price, trust, data excellent has no fine impact and huge have an impact on purchasing choices on the Shopee software in Surabaya.

Simultaneous test results (F test) confirmed that the variables of easiness, carrier quality, price, the trustworthiness of statistics fantastic and company image collectively impact the buy decision on the Shopee application in Surabaya.

\subsection{Recommendation}

With the results of research that states that service quality, price, trust, and quality of information have no partial effect on purchasing decisions, therefore the Shopee can make some improvements.

In the service quality variable can provide a sense of security for personal data and transaction data so that users don't feel afraid when making transactions on the Shopee application. In the information quality variable, it is expected that the palapa in Shopee provide clear, complete and appropriate information about the product, about the procedure for ordering products and payments, shipping and return procedures, or exchanging products. Shopee party as a marketplace should sort out what has a good rating from consumers in order to pay more attention and maintain trust in the quality of services provided to buyers involving the suitability of goods bought with totally informed. In order to succeed optimally, it is suggested to be able to maintain consumer confidence properly and increase the role of the transaction process by making constructive improvements. On the service quality variable, it is better to improve the purchasing decision of the Shopee to be able to maintain and guarantee the entire transaction process that runs smoothly and safely which will certainly have an impact on increasing purchases.

\section{References}

Abshor, M. U., Hasiolan, L. B., \& Malik, D. (2018, April). Pengaruh Harga, Promosi dan Kualitas Produk Terhadap Keputusan Pembelian Torabika Duo. Journal of Management., 4, 115. Retrieved November 30, 2019, from http://jurnal.unpand.ac.id/index.php/MS/articl e/view/1029/1004

Amaldoss, W., \& He, C. (2017, October 24). ReferenceDependent Utility, Product Variety, and Price. Management Science, 64(9), 3971- 4470. doi: 10.1287

Andrew, M. (2019, Februari 2). E-Service Quality and Brand Image on Buying Interest A Study of EService Quality and Brand Image on Shopee. Jurnal Sekretaris dan Administrasi Bisnis, 2338. doi:https://doi.org/10.31104/jsab.v3i1.83

Ayuningtiyas, K., \& Gunawan, H. (2018, Maret 29). Pengaruh Kepercayaan, Kemudahan dan Kualitas Informasi Terhadap Keputusan Pembelian Daring di Aplikasi Bukalapak Pada Mahasiswa Politeknik Negeri Batam. Journal of Applied Business Administration, 2(1), 152165. doi:doi.org/10.30871/jaba.v2i1.763 
Chin, W. W., \& Todd, P. A. (1995). On the Use, Usefulness, and Ease of Use of Structural Equation Modeling in MIS Research: A. MIS Quarterly, 19, pp. 237-246.

Davis, F. D. (1989). Perceived Usefulness, Perceived Ease of Use, and User Acceptance of Information Technology (Vol. 13). MIS Quarterly.

idEA. (2019, Februari Friday). idEA - Indonesian ECommerce Association. Retrieved November Kamis, 2019, from idEA Web site: https://www.idea.or.id/berita/detail/pasaridea-2019-hadir-untuk-pertama-kalinya-diindonesia

Lowry, P. B., Vance, A., Moody, G., Beckman, B., \& Read, A. (2014, Desember 1). Explaining and Predicting the Impact of Branding Alliances and Web Site Quality on Initial Consumer Trust of E-Commerce Web Sites. Journal of Management Information Systems, 24(3), 199-224. Retrieved november 2, 2019, from https://www.tandfonline.com/doi/abs/10.2753 /MIS0742-1222240408

Machali, I. (2018). Statistik Manajemen Pendidikan : Teori dan Praktik Statistik dalam bidang pendidikan, Penelitian, Ekonomi, Bisnis dan Ilmu - Ilmu Sosial Lainnya. Yogyakarta: Prodi Manajemen Pendidikan Islam bekerjasama dengan Perkumpulan Program Studi Management Pendidikan Islam (PPMPI).

Rizki, A. G., Hidayat, K., \& Rahma Devita, L. D. (2019, Juli 2). Pengaruh Citra Merek dan Harga Terhadap Keputusann Pembelian Pada ECommerce Shopee Indonesia ((Survei pada Mahasiswa S1 Fakultas Ilmu Administrasi Universitas Brawijaya Angkatan 2015/2016 dan 2016/2017 yang Membeli Barang Secara Online di E- commerce). Jurnal Administrasi Bisnis (JAB), 72, 49 - 56. Retrieved Desember 11, 2019, from http://administrasibisnis.studentjournal.ub.ac. id/index.php/jab/article/view/2865

Rozieqy, A., \& Arifin, R. (2018, Agustus 7). Pengaruh Kemudahan, Kepercayaan, Kualitas Informasi Dan Media Sosial Terhadap Keputusan Pembelian Secara Online Pada Shopee.Co.Id (Study Pada Mahasiswa Fakultas Ekonomi Dan Bisnis Unisma ). Jurnal Ilmiah Riset Manajemen, 7, 46-56. Retrieved November 20, 2019, from http://riset.unisma.ac.id/index.php/jrm/article/ view/1183

Sanjiwani, N. D., \& Suasana, I. A. (2019, November 03). Peran Brand Image Dalam Memediasi Pengaruh Kualitas. E-Jurnal Manajemen, $8(11)$, 6721-6740 doi:doi.org/10.24843/EJMUNUD.2019.v08.i 11.p17.
Suhir, M., Suyadi, I., \& Riyadi. (2014). Pengaruh Persepsi Risiko, Kemudahan dan Manfaat Terhadap Keputusan Pembelian Secara Online (Survei Terhadap Pengguna Situs Website www.Kaskus.co.id). Jurnal Administrasi Bisnis (JAB), 8, pp: 7. Retrieved from http://administrasibisnis.studentjournal.ub.ac. id/index.php/jab/article/view/355/549

Sutabri, T. (2012). Konsep Sistem Informasi. (Andi, Ed.) Yogyakarta.

Tanamal, R. (2019, November 3). What Is The Most Influential Factor On Decisions Using Youtube As A Tool To Support Buy Or Sell Means? (Case Study Surabaya City And Surrounding Area). Journal of Theoretical and Applied Information Technology, 97(20), 2407. Retrieved November 1, 2019

Wijaya, E., \& Warnadi. (2019, Juni). Factors Affecting Online Purchase Decisions At Shopee: Effect Of E-Commerce. Procuratio: Jurnal Ilmiah Manajemen, 7, 152-164. Retrieved 2019

Winkler, T., \& Wulf, J. (2019, Juni 14). Effectiveness of IT Service Management Capability: Value Co-Creation and Value Facilitation Mechanisms. Journal of Management Information Systems, 36(2), 639-675. Retrieved November 2, 2019, from https://www.tandfonline.com/doi/full/10.1080 /07421222.2019.1599513 